\title{
Pengaruh Ekstrak Bawang Hutan Eleutherine bulbosa (Mill.) Urb. Terhadap Perubahan pH Pada Stimulasi Pertumbuhan Probiotik Secara In Vitro
}

\author{
[The Effects Of Eleutherine Bulbosa (Mill.) Urb. Extract In Changing The $\mathrm{pH}$ In Stimulation \\ Of Growth Of Probiotics In Vitro]
}

\author{
Waode Munaeni $^{*}$, Widanarni², Munti Yuhana², Mia Setiawati², Aris Tri Wahyudi ${ }^{3}$ \\ ${ }^{1)}$ Program Studi Budidaya Perairan, Fakultas Perikanan dan Kelautan, Universitas Khairun, Jalan Raya \\ Pertamina Gambesi, Ternate, Maluku Utara, Indonesia, 97719 \\ ${ }^{2)}$ Departemen Ilmu Akuakultur, Fakultas Perikanan dan Ilmu Kelautan, Institut Pertanian Bogor, Jalan Agatis \\ Kampus Dramaga Bogor, Jawa Barat, Indonesia, 16680 \\ ${ }^{3)}$ Departmen Biologi, Fakultas Matematika dan Ilmu Pengetahuan Alam, Institut Pertanian Bogor, Jalan Agatis \\ Kampus Dramaga Bogor, Jawa Barat, Indonesia, 16680 \\ *Corresponding author : unalaspan@yahoo.co.id; waode.munaeni@unkhair.ac.id
}

\begin{abstract}
ABSTRAK
Bawang hutan Eleutherine bulbosa (Mill.) Urb.merupakan tanaman obat yang memiliki kandungan oligosakarida, berpotensi sebagai prebiotik yang mampu meningkatkan kesehatan usus udang vaname (Litopenaeus vannamei). Tujuan dari penelitian ini adalah menguji efek dari ekstrak bawang hutan dengan konsentrasi berbeda terhadap perubahan $\mathrm{pH}$ media pada stimulasi pertumbuhan probiotik secara in vitro. Konsentrasi ekstrak bawang hutan terdiri dari : 10, 5, 2.5, 1.25, 0.625, $0.313,0.156$ $\mathrm{mg} / \mathrm{mL}$. Bakteri probiotik yang digunakan adalah Pseudoalteromonas piscicida 1 Ub dan Bacillus $\mathrm{sp}$. NP5, sedangkan bakteri enterik menggunakan Vibrio parahaemolyticus. Waktu inkubasi selama 24 jam dengan pengamatan warna dan $\mathrm{pH}$ media dilakukan pada jam ke-0, 14, 18, dan 24. Hasil penelitian menunjukkan bahwa setelah inkubasi selama 24 jam terjadi perubahan warna dan $\mathrm{pH}$ media. Nilai $\mathrm{pH}$ pada perlakuan probiotik lebih rendah dibandingkan dengan bakteri enterik. Nilai $\mathrm{pH}$ pada $P$. piscicida 1Ub lebih rendah dibandingkan dengan Bacillus sp. NP5. Perubahan $\mathrm{pH}$ yang lebih rendah menandakan probiotik mampu memanfaatkan oligosakarida yang ada pada ekstrak bawang hutan.
\end{abstract}

Kata kunci : Eleutherine bulbosa, oligosakarida, pH, prebiotik, probiotik.

\section{ABSTRACT}

Eleutherine bulbosa (Mill.) Urb. is a medicinal plant that contains oligosaccharides, potential as a prebiotic that can improve intestinal health of white shrimp Litopenaeus vannamei. The purpose of this study was to examine the effect of $E$. bulbosa extract with different concentrations of changes in $\mathrm{pH}$ parameter of probiotic growth stimulation in the in vitro test. The concentration of E. bulbosa extract consisted of: $10,5,2.5,1.25,0.625,0.313,0.156 \mathrm{mg} / \mathrm{mL}$. The probiotic bacteria used were Pseudoalteromonas piscicida 1Ub and Bacillus sp. NP5. The enteric bacteria used was Vibrio parahaemolyticus. Incubation time for $24 \mathrm{~h}$ with observations starting at $0,14,18$, and $24 \mathrm{~h}$. The results showed that after $24 \mathrm{~h}$ of incubation the bacterial suspension was change in color and $\mathrm{pH}$. The $\mathrm{pH}$ value of the probiotic treatment was lower than the enteric bacteria. The $\mathrm{pH}$ value of $P$. piscicida $1 \mathrm{Ub}$ was lower than the Bacillus sp. NP5. The Lower of $\mathrm{pH}$ changes indicate that the probiotics is able to utilize oligosaccharides in E. bulbosa extract.

Keywords: Eleutherine bulbosa, oligosaccharides, $\mathrm{pH}$, prebiotic, probiotic

\section{PENDAHULUAN}

Penyakit telah menjadi masalah utama pada akuakultur hingga saat ini (Anderson \& Valderrama, 2019). Beberapa pendekatan alternatif telah dilakukan sebagai upaya untuk meningkatkan respons imun dan ketahanan terhadap penyakit seperti probiotik, prebiotik maupun kombinasi keduanya atau disebut juga sinbiotik. Penggunaan aplikasi ini telah diaplikasikan secara luas baik di ikan maupun udang (Dawood et al., 2017). Jenis probiotik seperti Pseudoalteromonas piscicida $1 \mathrm{Ub}$ dan Bacillus sp. NP5 telah terbukti mampu meningkatkan pertumbuhan, respon fisiologi, kesehatan ikan dan resistan terhadap bakteri pathogen penyebab penyakit.

Pseudoalteromonas piscicida $1 \mathrm{Ub}$ merupakan probiotik yang diisolasi dari naupli udang vaname (Widanarni et al., 2009), sedangkan Bacillus sp. NP5 merupakan probiotik yang diisolasi dari saluran pencernaan ikan nila (Putra et al., 2015). Seperti pada probiotik, peran prebiotik juga memiliki efek menguntungkan pada organisme akuakultur, mampu meningkatkan mikrobiota usus, kinerja pertumbuhan, respons imun, dan ketahanan terhadap penyakit (Song et al., 2014). 
Prebiotik merupakan bahan pangan yang dapat tidak dapat dimanfaatkan oleh inang (Carabin et al., 1999), tetapi dapat dicerna atau difermentasi secara selektif oleh mikrobiota dalam saluran pencernaan sehingga memberikan keuntungan pada inang (Gibson et al., 2004). Sumber prebiotik banyak diperoleh pada tanaman, salah satunya adalah bawang hutan Eleutherine bulbosa (Mill.) Urb. Selain memiliki potensi sebagai prebiotik, bawang hutan juga memiliki potensi sebagai antibakteri dan juga antioksidan. Oligosakarida yang ada pada ekstrak bawang hutan meliputi: fruktooligosakarida $(10 \%)$, rafinosa $(7.5 \%)$, inulin $(2.1 \%)$, dan galaktooligosakarida $1 \%$. Ekstrak bawang hutan mampu menstimulasi pertumbuhan Pseudoalteromonas piscicida 1Ub dan Bacillus sp. NP5 secara in vitro (Munaeni et al., 2020a), meningkatkan keragaman mikrobiota di usus pada udang vaname. Selain itu, bawang hutan juga mampu meningkatkan kesehatan usus udang seperti: meningkatkan aktivitas enzim pencernaan (protease, lipase, dan amilase), meningkatkan nilai rasio perimeter dan kerapatan mikrovili usus (Munaeni et al., 2020b) dan meningkatkan total bakteri di usus udang vaname (Munaeni et al., 2020c). Ha sil penelitian Phoem \& Voravuthikunchai (2013) juga menunjukkan bahwa $E$. americana diduga memiliki potensi sebagai sumber prebiotik mampu menjadi promotor untuk meningkatkan pertumbuhan mikrobiota usus yang di uji pada feses bayi.

Meskipun uji stimulasi pertumbuhan probiotik bawang hutan secara in vitro telah dilakukan, namun sejauh ini belum diketahui pengaruh terhadap perubahan $\mathrm{pH}$ media dari pertumbuhan probiotik tersebut. Menurut Mariana \& Usman (2019), parameter yang dapat digunakan untuk mengukur laju pertumbuhan probiotik dari pemanfaatan prebiotik seperti perubahan $\mathrm{pH}$, menurunnya keasaman, dan total bakteri probiotik. Penurunan nilai $\mathrm{pH}$ selama inkubasi/fermentasi mengindikasikan pertumbuhan bakteri yang menggunakan prebiotik sebagai sumber karbon. Aktivitas bakteri menghidrolisis prebiotik menjadi asam laktat menyebabkan penurunan $\mathrm{pH}$ (Setiarto, $d k k .$, 2016). Dengan demikian, penelitian ini bertujuan untuk menguji efek dari ekstrak bawang hutan dengan konsentrasi berbeda terhadap perubahan $\mathrm{pH}$ pada uji stimulasi pertumbuhan probiotik $P$. piscicida $1 \mathrm{Ub}$ dan Bacillus sp. NP5.

\section{BAHAN DAN METODE}

\section{Pembuatan ekstrak bawang hutan}

Umbi bawang hutan E. bulbosa diperoleh dari petani di Desa Kumbewaha, Kabupaten Buton, Provinsi Sulawesi Tenggara, Indonesia. Pembuatan ekstrak bawang hutan menggunakan metode maserasi bertingkat dengan pelarut etanol 96\% seperti dijelaskan pada penelitian sebelumnya (Munaeni et al. 2017).

\section{Persiapan Bakteri}

Bakteri yang digunakan pada penelitian ini terdiri dari 2 jenis yaitu bakteri probiotik (Pseudoalteromonas piscicida 1Ub dan Bacillus sp. NP5) dan bakteri enterik ( $V$. parahaemolyticus). $\quad V$. parahaemolyticus diperoleh dari Balai Riset Perikanan Budidaya Air Payau dan Penyuluhan Perikanan, Maros, Sulawesi Selatan. Sebelum digunakan untuk uji perubahan warna dan $\mathrm{pH}$, suspensi dari masing-masing bakteri dikultur menggunakan media SWC cair (sea water complete: $1 \mathrm{~g}$ yeast extract, $5 \mathrm{~g}$ bactopepton, $3 \mathrm{~mL}$ gliserol, 750 $\mathrm{mL}$ air laut, dan $250 \mathrm{~mL}$ akuades,) pada suhu 28-29 ${ }^{\circ} \mathrm{C}$ dengan kecepatan $140 \mathrm{rpm}$ selama 18 jam untuk $P$. piscicida $1 \mathrm{Ub}$ dan Bacillus sp. NP5. Sedangkan $V$. parahaemolyticus, dilakukan uji kurva pertumbuhan $V$. parahaemolyticus terlebih dahulu untuk mengetahui waktu inkubasi yang optimal menggunakan metode spektrofotometri pada absorbansi 600nm.

\section{Perubahan Warna dan pH dari Stimulasi Pertumbuhan Probiotik}

Uji perubahan warna dan $\mathrm{pH}$ mengacu pada penelitian sebelumnya dari stimulasi pertumbuhan probiotik dari ekstrak bawang hutan (Munaeni et al., 2020a) dengan modifikasi dari (Huebner et al., 2008). Ekstrak bawang hutan dengan perlakuan konsentrasi berbeda mulai dari konsentrasi rendah sampai tertinggi yaitu : A $(0.156 \mathrm{mg} / \mathrm{mL}), \mathrm{B}(0.3125$ $\mathrm{mg} / \mathrm{mL}), C(0.625 \mathrm{mg} / \mathrm{mL}), \mathrm{D}(1.25 \mathrm{mg} / \mathrm{mL}), \mathrm{E}$ $(2.5 \mathrm{mg} / \mathrm{mL}), \mathrm{F}(5 \mathrm{mg} / \mathrm{mL})$, dan G $(10 \mathrm{mg} / \mathrm{mL})$. Masing-masing perlakuan terdapat 3 ulangan. Sebanyak $1 \mathrm{~mL}$ dari masing-masing konsentrasi ekstrak bawang hutan ditambahkan pada media SWC cair $10 \mathrm{~mL}$. Perlakuan kontrol menggunakan media SWC saja dengan 
volume yang sama dengan perlakuan lainnya. Masing-masing dari suspensi bakteri yang telah dikultur dengan kepadatan $10^{8} \mathrm{CFU} / \mathrm{mL}$ diinokulasikan ke dalam perlakuan (v/v) sebanyak 5\%, kemudian diinkubasi menggunakan shaker dengan kecepatan 140 rpm pada suhu ruang $\left(28-29{ }^{\circ} \mathrm{C}\right)$ selama 24 jam. Pengamatan warna dilakukan sebelum inkubasi dan 24 jam inkubasi. Pengamatan perubahan $\mathrm{pH}$ dilakukan pada jam ke-0, 14, 18, dan 24 menggunakan $\mathrm{pH}$ indikator.

\section{Analisis Data}

Data

pertumbuhan

$V$. parahaemolyticus dan perubahan warna dari stimulasi pertumbuhan probiotik dari ekstrak bawang hutan dianalisis secara deskriptif sedangkan parameter perubahan $\mathrm{pH}$ dianalisis secara kuantitatif.

\section{HASIL}

Hasil uji kurva pertumbuhan bakteri enterik menunjukkan bahwa $V$. parahemolyticus mencapai fase stasioner mulai jam 10 sampai jam 18, kemudian menurun pada jam ke-20 (Gambar 1). Hasil ini kemudian menjadi acuan untuk penggunaan waktu inkubasi pada uji stimulasi pertumbuhan probiotik dari ekstrak bawang hutan yaitu mulai jam 0, 14, 18 dan 24. Hasil uji stimulasi pertumbuhan probiotik terhadap perubahan warna setelah inkubasi 24 jam menunjukkan adanya perubahan warna. Semakin tinggi konsentrasi, perubahan warna terlihat semakin keruh. Perubahan warna juga terlihat antara bakteri enterik $V$. parahemolyticus dan probiotik pada konsentrasi yang sama. Probiotik $P$. piscicida $1 \mathrm{Ub}$ lebih keruh dan warna ekstrak memudar dibandingkan Bacillus $s p$. NP5.

Perubahan $\mathrm{pH}$ pada $V$. parahemolyticus dari jam ke-0 hingga jam ke-14 tidak ada perubahan signifikan, kemudian pada jam ke14 hingga jam ke-24 tidak terjadi perubahan sama sekali (Gambar 3). Berbeda dengan $V$. parahemolyticus, perubahan $\mathrm{pH}$ terlihat jelas pada Bacillus sp. NP5 (Gambar 4) dan $P$. piscicida 1Ub (Gambar 5). Semakin tinggi konsentrasi ekstrak bawang hutan, perubahan $\mathrm{pH}$ semakin rendah hingga mencapai $\mathrm{pH} 5$ pada Bacillus sp. NP5 sedangkan $P$. piscicida menurun hingga $\mathrm{pH}$ 4. Nilai $\mathrm{pH} P$. piscicida lebih rendah dibandingkan Bacillus sp. NP5 pada konsentrasi dan waktu inkubasi yang sama.

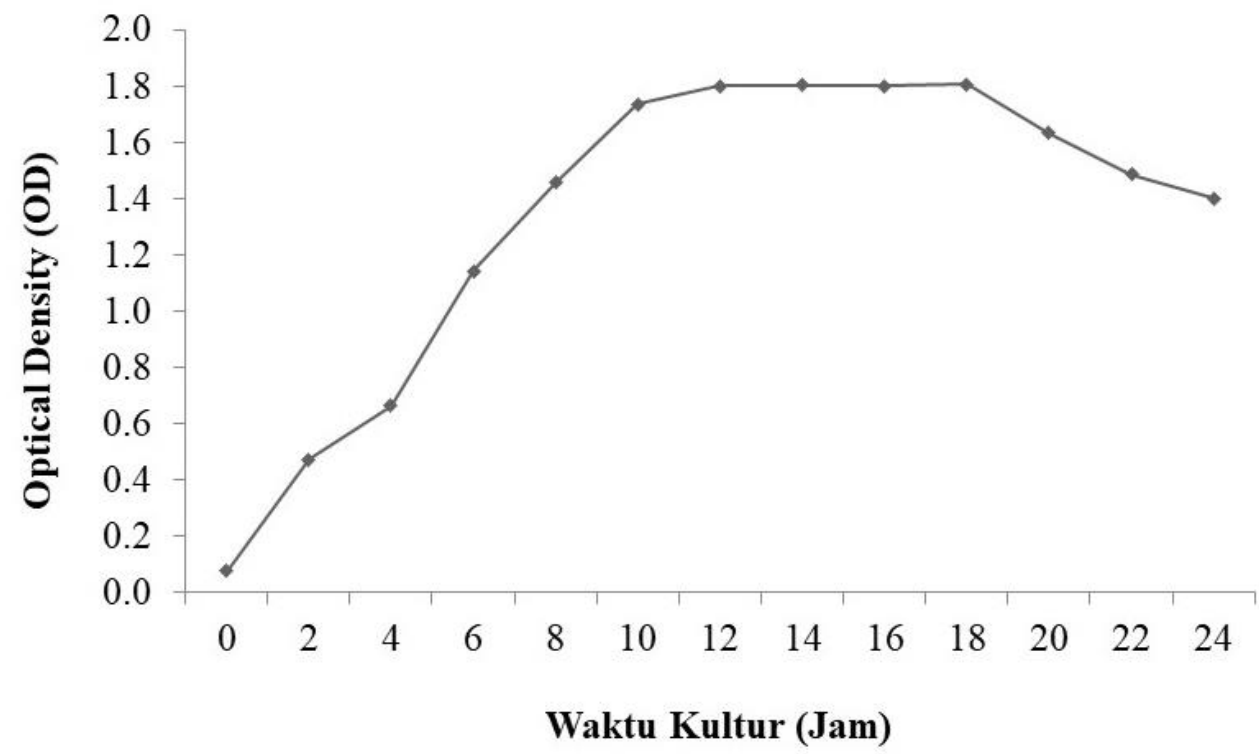

Gambar 1. Kurva pertumbuhan Vibrio parahemolyticus 

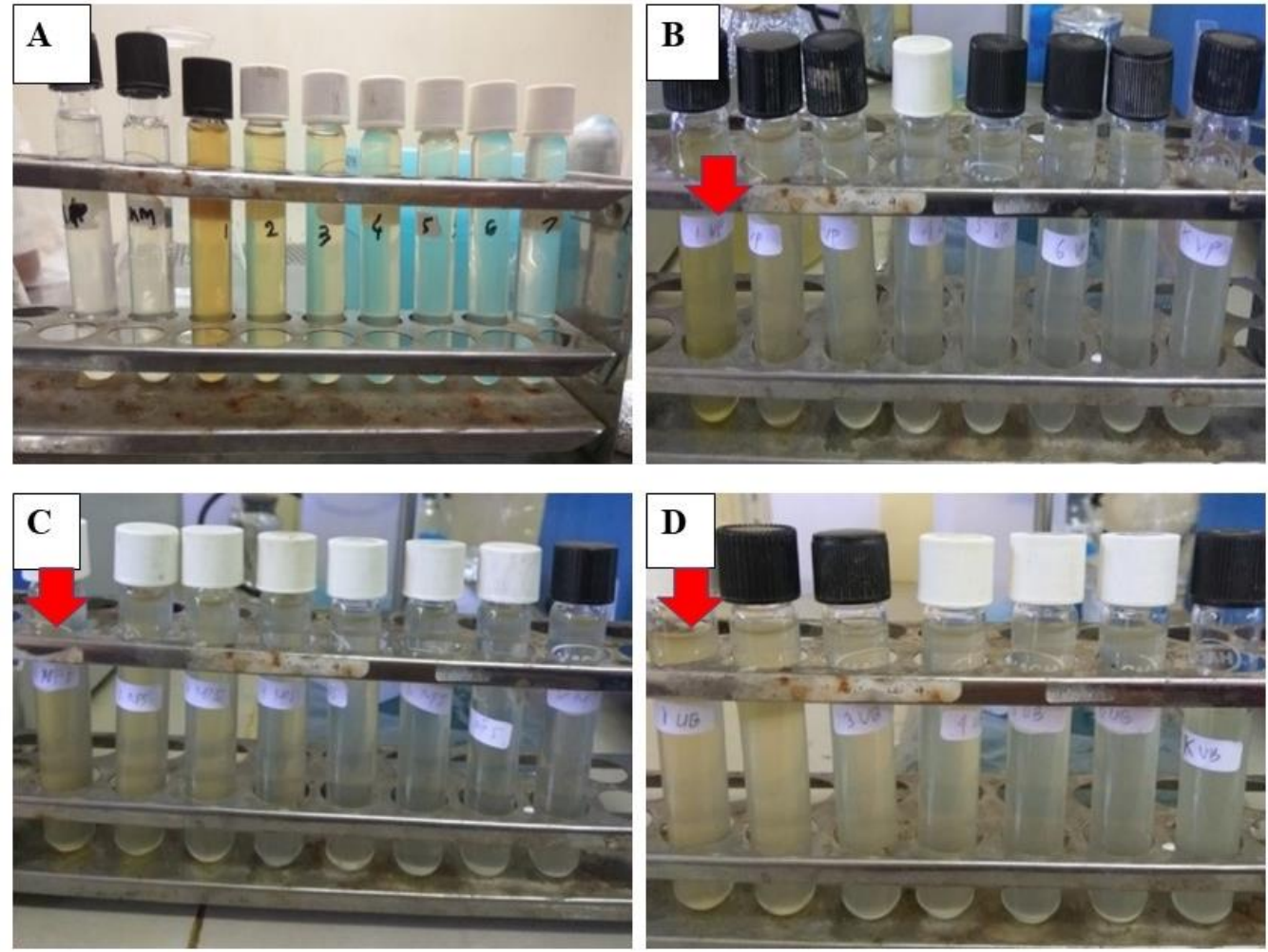

Gambar 2. Perubahan warna dari uji aktivitas ekstrak bawang hutan dengan konsentrasi berbeda terhadap stimulasi pertumbuhan bakteri patogen dan probiotik. Sebelum inkubasi : V. parahemolyticus (A); pasca inkubasi $24 \mathrm{jam}$ : V. parahemolyticus (B), Bacillus sp. NP5 (C), P. piscicida 1Ub (D). Tanda panah menunjukkan perbedaan perubahan kekeruhan pasca inkubasi.

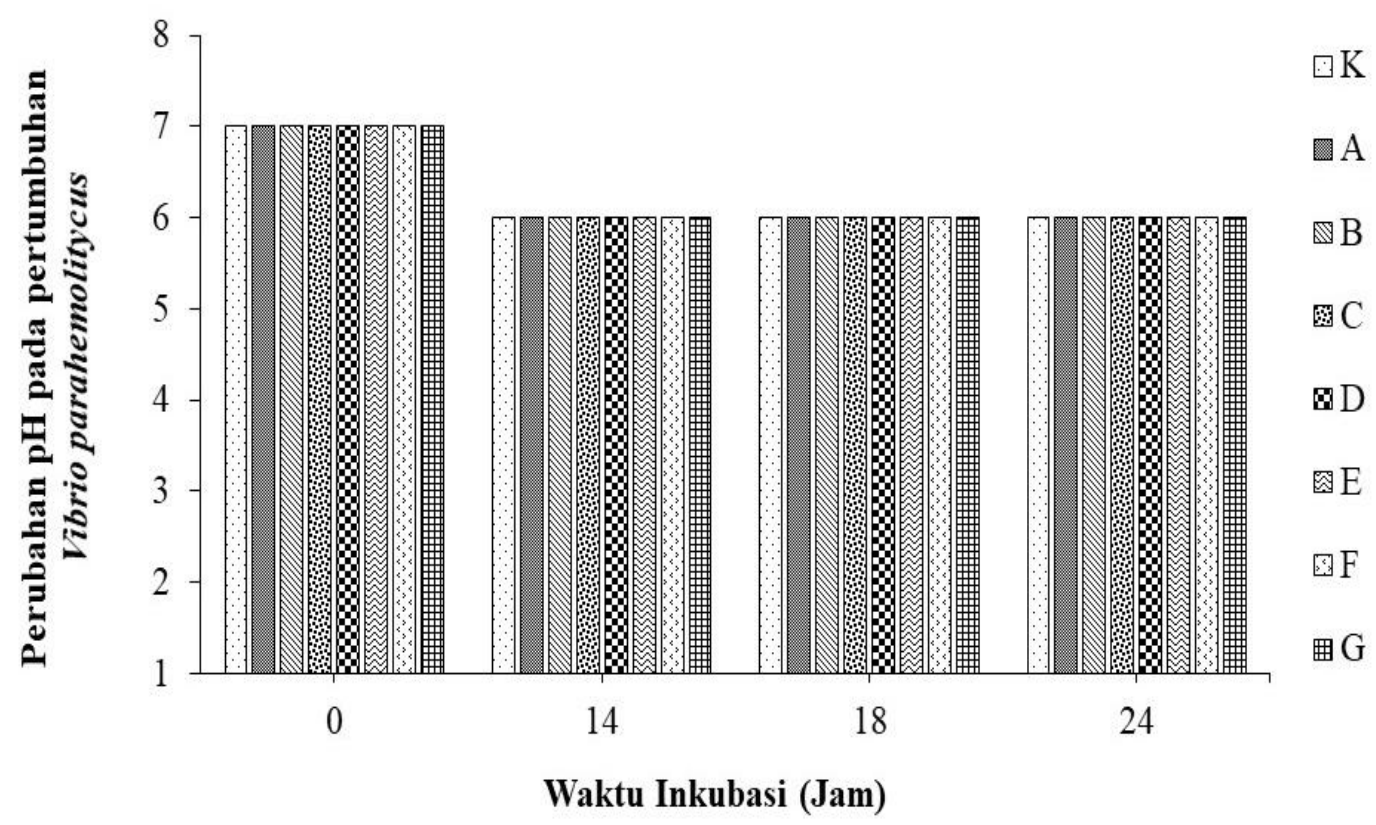

Gambar 3. Perubahan $\mathrm{pH}$ dari uji aktivitas ekstrak bawang hutan dengan konsentrasi berbeda terhadap stimulasi pertumbuhan V. parahemolyticus dengan waktu inkubasi berbeda. A $(0.156 \mathrm{mg} / \mathrm{mL})$, B $(0.3125$ $\mathrm{mg} / \mathrm{mL}), \mathrm{C}(0.625 \mathrm{mg} / \mathrm{mL}), \mathrm{D}(1.25 \mathrm{mg} / \mathrm{mL}), \mathrm{E}(2.5 \mathrm{mg} / \mathrm{mL}), \mathrm{F}(5 \mathrm{mg} / \mathrm{mL}), \mathrm{G}(10 \mathrm{mg} / \mathrm{mL} \mathrm{A})$. 


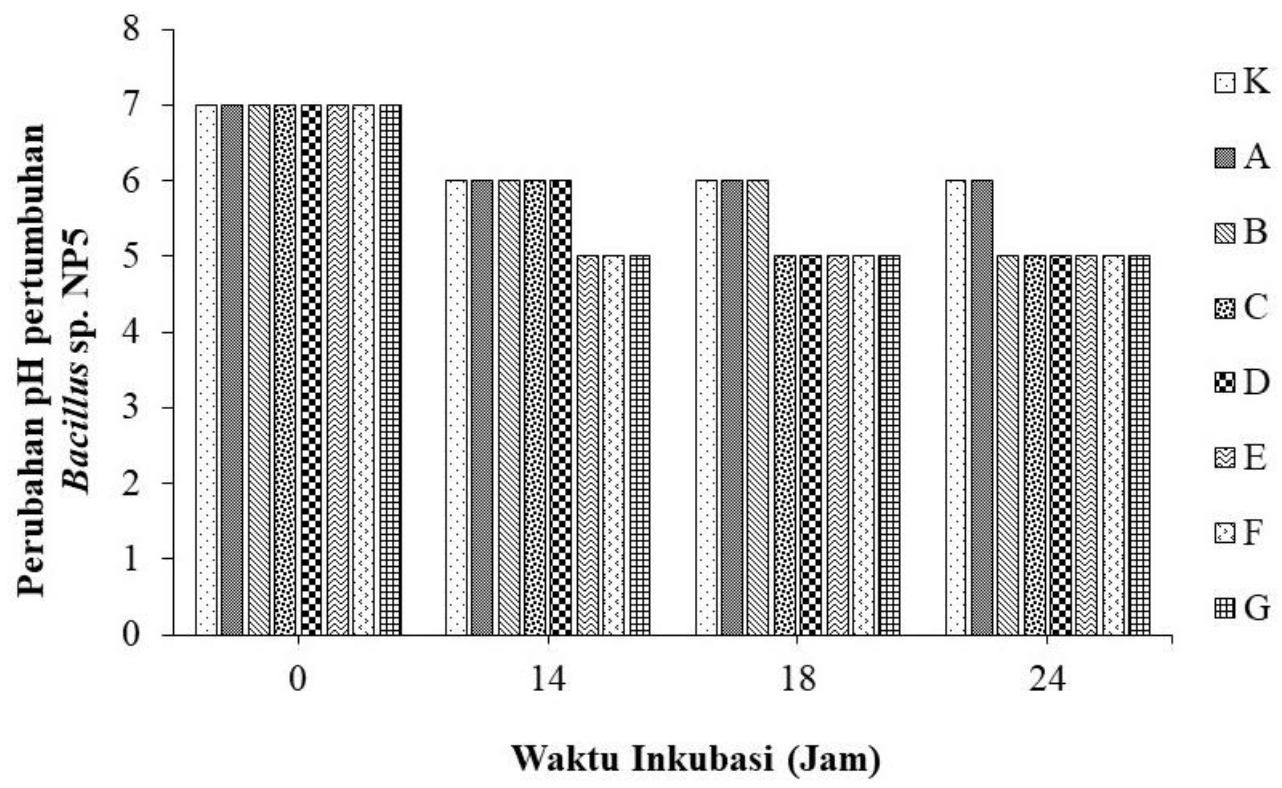

Gambar 4. Perubahan pH dari uji aktivitas ekstrak bawang hutan dengan konsentrasi berbeda terhadap stimulasi pertumbuhan Bacillus sp. NP5 dengan waktu inkubasi berbeda. A $(0,156 \mathrm{mg} / \mathrm{mL})$, B $(0,3125$ $\mathrm{mg} / \mathrm{mL}), \mathrm{C}(0.625 \mathrm{mg} / \mathrm{mL}), \mathrm{D}(1.25 \mathrm{mg} / \mathrm{mL}), \mathrm{E}(2.5 \mathrm{mg} / \mathrm{mL}), \mathrm{F}(5 \mathrm{mg} / \mathrm{mL}), \mathrm{G}(10 \mathrm{mg} / \mathrm{mL})$.

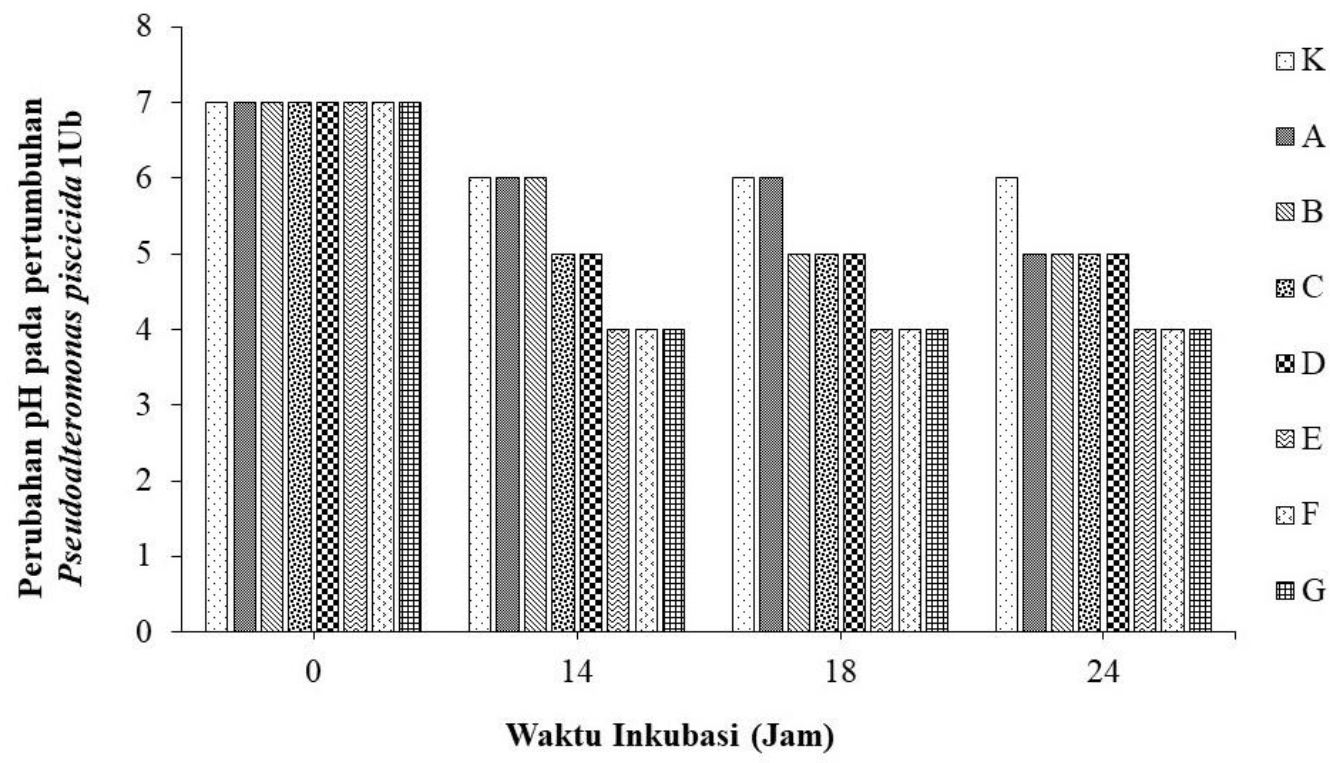

Gambar 5. Perubahan pH dari uji aktivitas ekstrak bawang hutan dengan konsentrasi berbeda terhadap stimulasi pertumbuhan $P$. piscicida $1 \mathrm{Ub}$ dengan waktu inkubasi berbeda. A $(0,156 \mathrm{mg} / \mathrm{mL})$, B $(0,3125$ $\mathrm{mg} / \mathrm{mL}), \mathrm{C}(0.625 \mathrm{mg} / \mathrm{mL}), \mathrm{D}(1.25 \mathrm{mg} / \mathrm{mL}), \mathrm{E}(2.5 \mathrm{mg} / \mathrm{mL}), \mathrm{F}(5 \mathrm{mg} / \mathrm{mL}), \mathrm{G}(10 \mathrm{mg} / \mathrm{mL})$. 


\section{PEMBAHASAN}

Perubahan $\mathrm{pH}$ dan warna atau kekeruhan media hasil penelitian ini menujukkan adanya pertumbuhan bakteri dengan memanfaatkan nutrien yang ada pada media maupun oligosakarida dari ekstrak bawang hutan sebagai sumber karbon. Menurut Sule et al. (2014), penurunan $\mathrm{pH}$ merupakan salah satu indikator pertumbuhan bakteri. Perubahan $\mathrm{pH}$, menurunnya keasaman, dan total bakteri probiotik merupakan parameter yang digunakan untuk mengukur laju pertumbuhan probiotik. Selama proses inkubasi akan terjadi penurunan nilai $\mathrm{pH}$ (Mariana \& Usman, 2019). Penurunan $\mathrm{pH}$ selama waktu inkubasi menunjukkan adanya proses fermentasi (Mariana \& Susanti, 2012). Rendahnya nilai pH pada perlakuan probiotik dibandingkan dengan bakteri enterik pada penelitian ini menunjukan bahwa probiotik $P$. piscicida dan Bacillus sp. NP5 mampu memanfaatkan oligosakarida yang ada pada bawang hutan sebagai sumber karbon. Menurut Setiarto $d k k$. (2016), semakin banyak jumlah inulin sebagai sumber karbon yang dapat dimetabolisme oleh probiotik, maka asam laktat yang dihasilkan juga semakin banyak sehingga menyebabkan $\mathrm{pH}$ semakin rendah.

Konsentrasi $0.625 \mathrm{mg} / \mathrm{mL}$ (C) dan 1.25 $\mathrm{mg} / \mathrm{mL}$ (D) dari stimulasi pertumbuhan $P$. piscicida dan Bacillus sp. NP5 masih menunjukkan penurunan $\mathrm{pH}$ pada jam ke-18 dan 24 sedangkan konsentrasi tertinggi di penelitian ini (E, F, dan G) menunjukkan penurunan terendah pada jam ke-14 dan tidak mengalami penurunan lagi hingga jam ke-24. Penurunan $\mathrm{pH}$ pada konsentrasi $\mathrm{C}$ dan $\mathrm{D}$ diduga tingginya pertumbuhan bakteri yang masih memanfaatkan oligosakarida ketika nutrien pada media telah habis. Menurut Mariana \& Usman (2019), penurunan pH tercepat terjadi dalam 8 hingga 10 jam karena pertumbuhan bakteri pada fase eksponensial. Selama fase eksponensial bakteri mengalami pembelahan sel dengan kecepatan maksimum. Kebutuhan energi pada fase ini cukup tinggi sehingga banyak laktosa dan karbohidrat lain yang difermentasi dan menghasilkan asam, terutama asam laktat. Pemecahan laktosa untuk membentuk asam laktat menyebabkan penurunan $\mathrm{pH}$ dari waktu ke waktu (Reza et al., 2016). Perbedaan $\mathrm{pH}$ antara perlakuan dibandingkan dengan kontrol kemungkinan disebabkan oleh kapasitas buffer dari komponen media tumbuh (Olson et al., 2012).

Konsentrasi E, F, dan G pada penelitian ini tidak mengalami penurunan setelah jam ke14. Hal ini diduga disebabkan menurunnya laju pertumbuhan bakteri. Terlihat dari penelitian sebelumnya bahwa pertumbuhan $P$. piscicida dan Bacillus sp. NP5 pada konsentrasi 2.5 $\mathrm{mg} / \mathrm{mL}, 5 \mathrm{mg} / \mathrm{mL}$, dan $10 \mathrm{mg} / \mathrm{mL}$ pada jam ke18 dan ke-24 lebih rendah dibandingkan konsentrasi $1.25 \mathrm{mg} / \mathrm{mL}$ dan $0.625 \mathrm{mg} / \mathrm{mL}$. Rendahnya pertumbuhan ini karena senyawa metabolit sekunder sebagai antibakteri dari bawang hutan lebih berperan dibandingkan dengan kemampuan oligosakarida. Konsentrasi optimum yang mampu menstimulasi pertumbuhan probiotik adalah $1.25 \mathrm{mg} / \mathrm{mL}$ (Munaeni et al., 2020a). Selain itu, lambatnya penurunan $\mathrm{pH}$ konsentrasi $1.25 \mathrm{mg} / \mathrm{mL}$ dan $0.625 \mathrm{mg} / \mathrm{mL}$ diduga karena saat inkubasi jam ke-14 sampai jam ke-18 terjadi stabilitas $\mathrm{pH}$ terjadi fermentasi. Hal ini dikemukkan oleh Mariana \& Usman (2019), suplementasi pollard sebagai prebiotik dengan kadar yang lebih tinggi menyebabkan stabilitas $\mathrm{pH}$ pada media fermentasi sehingga proses penurunan pH lebih lambat. Selanjutnya Salovaara (1998) juga menambahkan bahwa protein dan beberapa mineral memiliki kapasitas buffer yang tinggi. Kondisi $\mathrm{pH}$ yang stabil, pertumbuhan bakteri asam laktat lebih optimal karena terhindar dari adanya acidity shock.

Hasil penelitian ini juga menunjukkan bahwa kemampuan $P$. piscicida memanfaatkan oligosakarida yang ada pada bawang hutan lebih tinggi dibandingkan dengan Bacillus sp. NP5. Terlihat dari perubahan $\mathrm{pH}$ yang lebih rendah pada $P$. piscicida dengan konsentrasi dan waktu inkubasi yang sama. Perbedaan ini diduga disebabkan oleh ketersedian enzim yang ada pada probiotik untuk menghidrolisis oligosakarida yang ada pada ekstrak bawang hutan. Menurut Hamsah et al. (2017), P. piscicida mampu memproduksi enzim lipase, protease, amilase dan manannase. Keberadaan bakteri menguntungkan pada saluran pencernaan seperti Pseudoalteromonas sp. dapat meningkatkan aktivitas enzim pencernaan seperti amilase, tripsin, dan lipase (Amoah et al., 2019). Sedangkan menurut Putra et al. (2015), Bacillus sp. NP5 mampu memproduksi enzim amilase, protease, dan lipase. 


\section{KESIMPULAN}

Nilai $\mathrm{pH}$ pada perlakuan probiotik lebih rendah dibandingkan dengan bakteri enterik. Semakin tinggi konsentrasi ekstrak bawang hutan, perubahan $\mathrm{pH}$ semakin rendah. Nilai $\mathrm{pH}$ pada $P$. piscicida $1 \mathrm{Ub}$ lebih rendah dibandingkan dengan Bacillus sp. NP5. Perubahan $\mathrm{pH}$ yang lebih rendah menandakan probiotik mampu memanfaatkan oligosakarida yang ada pada ekstrak bawang hutan.

\section{REFERENSI}

Amoah, K., Huang, Q.C, Tan, B.P., Zhang, S., Chi, S.Y., Yang, Q.H., Liu, H.Y., Dong, H.Y. (2019). Dietary supplementation of probiotic bacteria, Bacillus coagulans ATCC 7050, improves the growth performance, intestinal morphology, microflora, immune response, and disease confrontation of Pacific white shrimp, Litopenaeus vannamei. Fish \& Shellfish Immunology, 87, 796-808. https://doi.org/10.1016/j.fsi.2019.02.02 9

Anderson, J.L., Valderrama, D., Jory, D. (2019). GOAL 2019: Shrimp Production Review. Chennai, India. Oktober 2019. Pp 1-58.

Carabin, I.G, Gary F.W. (1999). Evaluation of safety of inulin and oligofructose as dietary fiber. Regulatory Toxicology and Pharmacology, 30(3), 268-282. https://doi.org/10.1006/rtph.1999.1349

Dawood, M.A.O, Koshio, S., Esteba, M.A. (2015). Beneficial roles of feed additives as immunostimulants in aquaculture: a review. Reviews in Aquaculture, 10(4), 950-974. https://doi.org/10.1111/raq.12209

Gibson, G.R., Probert, H.M., Rastall, R.A., Roberfroid, M.B. (2004). Dietary modulation of the human colonic microbiota: updating the concept of prebiotics. Nutrition Research Reviews, 17(2), 259-275.

Hamsah, Widananrni, Alimudin, Yuhana, M., Zairin, M. (2017). The nutritional value of Artemia sp. enriched with the probiotic Pseudoalteromonas piscicida and the prebiotic mannanoligosaccharide. AACL Bioflux, 10(1), 8-17.
Huebner J, Wehling RL, Parkhurst A, Hutkins RW. (2008). Effect of processing conditions on the prebiotic activity of commercial prebiotics. International Dairy Journal, 18(3), 287-293. https://doi.org/10.1016/j.idairyj.2007.0 8.013

Mariana, E., Susanti, H. (2012). Pengaruh suplementasi tepung terigu terhadap pertumbuhan dan laju pengasaman probiotik Lactobacillus acidophilus. Jurnal Teknologi dan Industri Pertanian Indonesia, 4(3), 14-19. https://doi.org/10.17969/jtipi.v4i3.738

Mariana, E., Usman, Y. (2019). Effect of pollard supplementation on probiotic (Lactobacillus acidophilus) growth and acidification rate. IOP Conference Series: Earth and Environmental Science, $\quad 387, \quad 012028$. DOI:10.1088/1755-1315/387/1/012028

Munaeni, W., Pariakan, A., Yuhana, M., Setiawati, M., Abidin, L.O.B. (2017). In vitro phytochemicaland inhibitory potential tests of Buton forest onion extract Eleutherine bulbosa (Mill.) Urb. on Vibrio harveyi. Journal Microbiology Indonesia, 11(3), 75-80.

Munaeni, W., Widanarni, Yuhana, M., Setiawat, M., Wahyudi, A.T. (2020a). The potential of Buton forest onion Eleutherine bulbosa (Mill.) Urb. extract as a prebiotic and an antioxidant. Journal of Microbiology, Biotechnology and Food Sciences 10(1), 107-111. https://doi.org/10.15414/jmbfs.2020.10 $.1 .107-111$

Munaeni, W., Widanarni, Yuhana, M., Setiawat, M., Wahyudi, A.T. (2020b). Impact of dietary supplementation with Eleutherine bulbosa (Mill.) Urb. on intestinal microbiota diversity and growth of white shrimp, Litopenaeus vannamei. Aquaculture, 528, 735466. https://doi.org/10.1016/j.aquaculture. 2 020.735466

Munaeni, W., Widanarni, Yuhana, M., Setiawat, M., Wahyudi, A.T. (2020c). Effect in white shrimp Litopenaeus vannamei of Eleutherine bulbosa (Mill.) Urb. Powder on immune genes expression and resistance against Vibrio parahaemolyticus infection. 
Fish \& Shellfish Immunology, 102, 218-227.

https://doi.org/10.1016/j.fsi.2020.03.06 6

Olson, D.W., Kayanush, A. (2012). Effect of prebiotics on Lactobacillus acidophilus growth and resulting $\mathrm{pH}$ changes in skim milk and a model peptone system. Journal of Microbial and Biochemical Technology, 4(5), 121125.

Putra, A.N., Utomo, N.B.P, Widanarni. (2015). Growth performance of tilapia Oreochromis niloticus fed with probiotic, prebiotic and synbiotic in diet. Pakistan Journal Nutrition, 14(5), 263-268.

Phoem, A.N, Voravuthikunchai, S.P. (2013). Eleutherine americana as a growth promotor for infant intestinal microbiota. Anaerobe, 20, 14-19. https://doi.org/10.1016/j.anaerobe.201 3.01 .004

Reza, M.A., Hosain, M.A., Lee, L.J., Kim, J.C., Park, S.C. (2016). In vitro prebiotic effects and quantitative analysis of Bulnesia sarmienti extract. Journal of Food and Drug an Analysis. 24(4):822-830.

https://doi.org/10.1016/j.jfda.2016.03.0 15

Salovaara, H. (1998). Lactic acid bacteria in cereal based products. Mc Grawhil Book Co. Inc., New York.

Setiarto, R.H., Widhyastuti, N., Saskiawan, I., Safitri, R.M. (2016). Pengaruh variasi konsentrasi inulin pada proses fermentasi oleh Lactobacillus acidophilus, Lactobacillus bulgaricus dan Streptococcus thermophilus. Biopropal Industri, 8(1), 1-17. http://dx.doi.org/10.36974/jbi.v8i1.166 9

Song, S.K., Bo, R.B., Kim D, Park J, Kim J, Kim HD, Ringø E. (2014). Prebiotics as immunostimulants in aquaculture: A review. Fish \& Shellfish Immunology, 40(1), 40-48. https://doi.org/10.1016/j.fsi.2014.06.01 6

Sule, J., Korosi, T., Hucker, A., Varga, L. (2014). Evaluation of culture media for selective enumeration of bifidobacteria and lactic acid bacteria. Brazilian
Journal of Microbiology. 45(3), 102330 . https://doi.org/10.1590/S151783822014000300035

Widanarni, Tepu, I., Sukenda, Setiawati, M. (2009). Selection of probiotic bacteria for biocontrol of vibriosis on tiger shrimp Penaeus monodon larvae using co-culture method. Jurnal Riset Akuakultur, 4(1), 95-105. 